\title{
THE CHANGING SOCIAL SETTING OF ALIMONY LAW
}

\author{
ROBERT W. KELSO*
}

The ultimate validity of any principle of law, and consequently of all written rules of public order based thereon, rests upon social need. It is the aim of all men, related to each other in that nexus of physical and mental contacts which we call "society," to live happily and at peace. To that end is the conduct of the individual regulated. Through the long experiment of trial and error, neighborhood and tribal custom works itself out into principles of personal conduct. The resulting body of the unwritten law becomes the self-imposed regimen of a free and self-determining people.

If this reasoning be sound, it must follow that changes in social need call for corresponding changes in rules of law; that the law must be a changing, growing structure, responding to those constant alterations in environment which society experiences as a result of man's continuing conquest of the forces of nature and the resources of the earth. Law is not static.

Careful perusal of the following articles in this symposium will reveal the origin, the historical development and the legal reasoning upon which the modern law of alimony rests. It is the purpose of this article to explore with some thoroughness the social setting surrounding this legal principle, with intent, if possible, to identify those social determiners which justify the rule and those which may indicate change: and finally to identify such change as seems advisable in the premises.

Concerning this social matrix for the law of alimony three considerations call for some analysis. The first is the function and importance of the family; the second, the principle of self-support in a free people; and the third, the question whether the status of woman under coverture has so for changed as to call in itself for change in the present law of alimony.

And first as to the family as an institution in human society. Modern man's acceptance of monogamy as the best form of family structure is often said to result from his increasing sense of morality. In all probability his alleged increase in moral appreciation has nothing to do with his attitude toward the family; or if it does, it is result rather than cause. The mating of a single pair and their continuance in ex-

- A.B., 1904, LL.B., I907, Harvard University. Member of Massachusetts Bar. Professor of Social Service, University of Michigan, and Director of the Michigan Graduate Institute of Public and Social Administration, Detroit, since I935; Chairman, Michigan State Housing Commission, since r938. Executive Secretary, Boston Council of Social Agencies, 1921-x929; Director, St. Louis Community Fund and Council, r929-x932. President, National Conference of Social Work, x922. Author of History of Public Poor Relief in Massachusetts (x922); The Science of Public IVelfare (1928); Poverty (I929). 
clusive mated relationship tends to guarantee continuous and devoted attention to the wants of their offspring throughout its inordinately long period of helplessness. This service of parent to child is a necessity of the species. The best way to get a "good standing foal" and to guarantee its upbringing to competence is the best mating arrangement, morals aside. Polygamous or promiscuous matings might and probably would increase numbers of offspring, but they could not guarantee that long and faithful attention to helpless infancy so necessary to racial and social improvement.

If the family then is to consist of one male and one female with the offspring, issue of the mating-because this is among all possible forms of mating the most likely to advance society-it must follow that dangers and impairments of this monogamous family must be fended off and a cloak of protection placed about the institution to guard it. Of all things else, the protection of man's breeding lair is his deepest concern. Wherefore we say with truth that the family is the basis of society.

The far ramifications of the law of persons and of property aim to safeguard the institution of the family: and our moral tenets as distinguished from law tend to the same end. It is because our increasing knowledge of heredity warns us of the care needed in mating; the dangers of breeding from the in-blood; the destructive effect of mental subnormality when of hereditary origin, that chastity in both spouses is a virtue. We often explain it on other grounds, but this is the real reason.

It is a logical step from social recognition of the family as a vital foundation to the requirement that every reasonable effort must be made within the family to keep it independent and self-supporting. In earlier times the husband had all the property, and all the opportunity to gain property. The wife was the housekeeper, rendering her services in childbearing and in home duties, without compensation. Obviously it must fall to the husband to support the family. And the State from the beginning has done its best to see to it that he did his duty.

He was responsible for the wife's debts and even for her torts. She was a complete dependent upon her husband and, except in matters of her own wrongdoing, could demand of him the full measure of support. It was in this era of total wife dependency and nonentity at law that the equitable rule of alimony sprang up in chancery.

Marriage in that age was a sacrament, permitted by the Church which was the State, conceived in spiritual bonds, hedged about by dogmatic commandments of ecclesiastical rule. ${ }^{x}$ Transgression of the moral precepts enjoined upon the married pair was the abiding fault in marital conduct. It was sin. Economic insufficiency, mere social inadequacy, unhappiness and misery too deep for tears-these were not among the conditions that were correctable, unless mayhap they were coupled with someone or other of the forbidden sins. Hence the persistent rule that he or she who was not completely innocent of moral offense was denied redress. ${ }^{2}$ Only the innocent

\footnotetext{
${ }^{2}$ See 2 Pollock \& Maitiand, History of English Law (1927) 336.

${ }^{3}$ See Bradway, The Myth of the Innocent Spouse (1937) II TulaNe L. REv. 377, at 379, and cases cited.
} 
spouse had standing in court. American statutes are today still surcharged with this earlier concept of guilt and innocence in issues of divorce and alimony. ${ }^{3}$

The ecclesiastical doctrine of alimony was no more than an enforcement of the husband's duty to support. The wife could not enforce it at law: equity found a way. The doctrine thus set up related to the married status only, and therefore had no place after a decree of absolute divorce. At most it gave remedy to the wifenever to the husband-who was separated from her spouse for cause.

Why should the law strive specially for the enforcement of the husband's duty? Legal decrees do not mend attitudes of hostility and unhappiness. Granted that the marriage tie is precious to the State as signifying the possibility of new citizens, can an order to the husband that he must do his duty-already understood-or suffer penalty bring about any sweetening of the strained condition of things? This query brings forward the second consideration in this discussion, namely, how vital is individual self-support in a free nation?

In this present year, when government is expending such large sums in the relief of persons dependent through lack of employment the question of self-support may well be pondered. 4 The individual who is dependent upon somebody else for food, clothing and shelter may, and often does, lose his self-reliance and his will to go forward in life. But more important even than this result is the harm that may come to him as a free agent in the exercise of his rights as a citizen. If the government supports him it must take the means of that support from some other citizen, almost invariably a citizen who has earned it by hard work, and who, in addition to that earning, has been supporting his own family as the law requires. The individual thus aided is in grave danger of losing his right to independent decision at the polls. But the greatest danger of dependency is its menace to personal freedom, and loss of the will to strive for independence. Its ugliest manifestation is the resulting insecurity of home life.

A government which exists by consent of the governed, and in which the will of the people is the final expression of power, can exist to its fullest degree of effectiveness only when each individual within it is as free and independent as possible, and as free as possible from the burdens properly belonging to other individuals. Selfsupport is the bed rock of freedom under law, and consequently the foundation of empire based upon that freedom.

Economic insecurity due to uncertainty of income and of the job by which that income is earned, is the primal discouragement in home building. Studies in marriage frequency indicate a close correlation between the frequency of marriage and the business cycle upon which security on the job depends. Indeed the curve of mar-

\footnotetext{
${ }^{3}$ Among the many expressions on the point is that in Capell v. Capell, r64 Va. 45, 49, x78 S. E. 894 , 895 (1935). The court said, "A decree for alimony is more than an order for the payment of money. A husband who has wronged his wife must continue to contribute to her support." In this case the decree was for absolute divorce.

The total spent by governments in the United States for emergency relief and work relief, I933 to I938 inclusive, was \$I7.5 billion. See Report of U. S. Senate Committee on Unemployment Relief (1939) Soc. Sec. Bd. Release No. 7 Ix, Feb. 12, 1939.
} 
riage frequency follows the business curve with almost complete parallelism. ${ }^{5}$ The likelihood of income enough to support home and children is the harrowing "if." It harries the young who plan marriage: it haunts them as man and wife: it is the specter that looms in the form of anticipated dependency when the marriage turns out badly.

Looking squarely at the conditions surrounding the American home, it becomes apparent that family life is not a moral state of grace: rather it is a social status necessary to the right perpetuation of the species, cast in a setting of stern economic limitations. The chief party in interest is the State, which never appears formally as a party litigant and is too often forgotten in the reasoning of the custodians of the law. Nevertheless the family is the human institution most vital to the perpetuation of the race, and its sound ordering the consideration of deepest social concern. ${ }^{6}$

It may be profitable at this point to ask the social as distinguished from, the legal question, who are the real parties in interest in an issue of marital trouble involving alimony? 'The chief and foremost party in interest, as just noted, is the State. It has sanctioned the marriage. It has laid down the terms of the contract into which the spouses enter; has maintained a constant oversight of its performance, regulating it by the law of the domicile rather than that of the contract itself. It alone permits its dissolution, and then only by solemn decree. The life of the State is made possible only through the propagation of succeeding generations; and its social validity depends directly upon the physical and mental competence of the offspring propagated and nurtured through the instrumentality of the family mating.

Next in interest come the children, if any. These are the true assets of the State. For as Emerson has phrased the concept, "The true test of civilization is, not the census, nor the size of cities, nor the crops-no, but the kind of man the country turns out." It is the child who is by definition dependent and helpless. He must be protected against privation at all hazard, let the cost to other parties in the issue be what it may. It was for him as a new being in society and a prospective citizen in the State that the marriage was entered into. It was for him that the State has taken such care in the fixing of the marriage terms and in the oversight of the marital conduct of his parents. When all else has ceased to be of worth or validity, it will be he who stands out, disadvantaged and a dependent upon the bounty of the State, to develop into an adulthood of competence in spite of the odds-or of incompetence, perhaps crime, because of the odds.

And finally come the actual parties litigant, the spouses seeking to settle their difficulty by means of the equitable decision of the State through its instrument, the court. These are the parties who make all the claims and suffer all the legal penalties. It is they of whom the law has said, "he that cometh into court must come with clean

${ }^{5}$ For a striking illustration of the coincidence of these two curves, see the supplemental statistical survey issued in January, 1939 , by the University of Buffalo, Bailey and Carpenter, Marriage and Economic Fluctuations in Buffalo, 1921-1938, 14 Burenu of Bus. \& Soc. ReseArch, No. 5a.

- As some slight indication of the public stake in the problem of family support, it is uniformly held that the parties to a decree for alimony may not deprive the court of its continuing power over its terms by any subsequent agreement modifying or abrogating it. See (1935) 49 U. S. L. REv. 56r-569, and cases cited.

${ }^{7}$ EMerson, SOciety and Solitude. 
hands." And it is they alone who stand out in the minds of legislatures where they cling to the idea of "guilt and innocence" in declaring the rights and obligations in divorce litigation.

From a social point of view, therefore, the court in the contemplation of divorce and disposition of property of the spouses should consider, first, the well-being of the State-the whole people; second, and hardly separable from the first, the support and well-being of the children; and third the support of the spouses and the equitable division of their property involved in the marriage. In this light moral guilt or innocence is of little importance beyond the possible but doubtful deterrent effect of the "rule of the innocent spouse" upon potential offenders against marital duty.

If these preliminary considerations are sound it must be obvious that the struggle for a living by the individual, and for standards of living by society, requires that marriage, which is the legal sanction for the family, be freely entered into and freely dissolved, within the limits of sound public policy. And these results must be made possible without shaking the structure of the whole of society, identified in this article by the word "State." In all ways feasible the State must encourage marriage; cloak it about with protections; and recognize the need of its recession in the event of failure to meet the objectives for which it exists.

Yet in the face of this necessity for the encouragement and protection of our basic social institution-identical in condition and function the world over-we find an astounding confusion of thought arising out of the anchorless attitudes of courts and legislatures throughout the nation.

The historical remains of the older philosophy of the Church as the State still makes for marked confusion in legal rules of conduct on the one hand and our moral tenets resting upon attitudes, emotions and beliefs on the other. It is because of this confusion chiefly that we find the statutes of our several jurisdictions varying markedly in their appraisal of what constitutes sound public policy in the legal sanctions of marriage; as to who may marry; as to how the contract may be entered into; as to how regulated; and in particular as to how and under what conditions it may be dissolved. This astonishing range of variation in our laws governing marriage and divorce is a tribute less to provincialism than to ignorance of the true philosophy of social order.

One marriage in six in the United States results in divorce. ${ }^{8}$ This is the demonstrated degree of mésalliance. Social workers know how high above this percentage rises the total of separations and of marital unhappiness and distress without separation. Yet we find one of our jurisdictions (South Carolina) refusing to sanction dissolution of marriage by divorce. Other jurisdictions find moral and ethical behavior the criteria of virtue in marriage. Seldom does the law-and then only in a fragmentary way-recognize the hard fact that economic distress, the filth of bad housing, the meagerness of home interest, the cruelties of social ostracisms, and over all the black shadow of dire poverty are causes of conduct for which moral or immoral attitudes are seldom more than sequelae.

${ }^{8}$ Ogburn, The Family and its Functions, I Recent Soctar Trends (1933) c. 13. 
If a spouse is "good" according to ecclesiastical tenets of morality he may, by the law of some jurisdictions, insist upon the continuance of a status in family life that is in fact anti-social, since the State cannot divorce him and neither can his spouse. If his conduct offends those same tenets he may be, and often is, barred from claiming such status as the conditions of economic life require for the protection of society. For instance, the wife who offends the moral tenets of the day may not claim that support without which she may become a public dependent or a prostitute.

So long as we fail in our legal structure to take account of the economic limitations upon conduct that change from one epoch to another-indeed from one single decade to another-we remain in danger of maintaining a social order dictated by a majority group of believers to control those who by their conduct are apostate. The problem of the stomach, the hungry personality struggling for some enlargement or expression of itself-the outraged sense of justice rebelling against oppression, the sick mind struggling to readjust itself-all these are but the circumstances of life and are not admissible in evidence.

The record of one childless couple in every six matings in the United States today argues no physical change in the fecundity of the race. It arises from other causes, some of which must certainly result from the legal strictures upon change in the marriage status in the face of sound social expediency.

If it is true that the marked variations in American statute laws governing marriage and divorce have no foundation in social policy or the logic of the law, is it practicable to find common ground upon which legislatures should act in the development of the written law of this subject?

It is here submitted that a frank and straightforward attitude toward the plain circumstances of living in America today would improve the legislative concept of family life. A vision of a self-supporting population constituting a purposeful society would throw emphasis upon the need for individual self-support, affording to the law of alimony a concept now largely neglected.

The third inquiry into the social setting of the family here proposed is embodied in the question: has the position of woman in the marriage relation so far altered as to render change advisable in our legal attitude toward alimony?

When the ecclesiastical courts first devised the equitable remedy of alimony, the wife had no standing before the law courts: chancery discovered her plight to be one of lack of remedy at law and lack of means to protect herself even in the event that a day in court could be accorded her. It gave her the right therefore to sue in equity for protection against the husband, even to the extent of separation from bed and board; and, in order to make that decree practicable, called upon the husband to continue to support her, wherever she had no means of support; but only in such case of need. This was the limit of protection granted her.

It was never contemplated that she could demand or secure a complete severance of the bonds of matrimony. Much less did it contemplate her continued support after such abrogation. As a wife she was suffering an injustice. The husband was an offender against some one or more of the moral obligations laid upon him by the 
Church. His offense was serious enough to justify his wife's separation from him a mensa et thoro. She was innocent of any violation of the moral obligations placed similarly upon her. As punishment he must lose the consortium yet go on with the obligation to support her. The children of the mating seem never to have been visible above any horizon of the law.

But since that early day the conditions of living and labor attending the family's struggle for social competence have changed materially, and with that change has come a corresponding change in the position of the woman under coverture. The older pattern of the family hearth in a cottage on the heath-a bucolic existence set in rustic peace-has given way to a mechanized world in which man has largely traded his assured dependence upon the soil for the drab uncertainties of a job set in an urban struggle for mere existence. In this new environment the wife must toil to keep the semblance of home; but she must do more. In order to eke out the family income she must go outside the home and labor in common with husband and children at a job. To an increasing degree she must take her turn at bread winning. ${ }^{9}$ And in this extension beyond the walls of home she makes constant and more or less intimate contact with other persons, both men and women. She receives thereby a social enlargement which extends her interests and sympathies and emotions far beyond the limits of her own marital fireside. More anciently she was mainly a consort, kept in her husband's home for purposes of companionship and propagation. Now she has become a social person, quite equal with her husband, thoughtful of civic and public affairs, concerned with matters political, interested in the broader things of life. To an increasing degree today she takes the initiative in family support and family progress.

So completely has she become the coordinate and collaborator with her husband in family support that the law has gradually, by one step after another, recognized her parity. Thus she may now hold property independently of her husband.10 She may enter into contractual relations independently of him. ${ }^{11}$ She may enter into contracts directly with him. ${ }^{12}$ She may sue him and be sued by him in matters not directly touching the marriage contract. ${ }^{13}$ Though the words of the marriage ceremony still admonish her to "love, honor and obey" him, she is not obliged to do any one of those things; and the law is powerless to compel her to do so. ${ }^{14}$ She may leave him and sue him for absolute divorce upon a multiplicity of grounds touching happiness and personal freedom rather than mere marital faithfulness. ${ }^{15}$ She may vote and her secret ballot is none of his legal concern. From her old position as an identity merged in him and not separable from him, she has advanced to a position of independence in most respects fully equal with his. Whereas in the period when

\footnotetext{
${ }^{B}$ It is estimated that approximately one sixth of the married women of the United States work outside the home at an earning occupation, the proportion having increased sixfold sinca the turn of the century. For a careful summary of data on this head, see Breckinridge, The Activities of Women Outside the Home, I Recent Sociaz Trends (1933) c. I4.

10 See Schouler, Domestic Relations (6th ed. I905) \$\$145, 186.

${ }^{11} I d . \$ \$ 227,229$.

${ }^{12}$ Id. $\$ 539$.

${ }^{14}$ Id. $\$ 54$.

${ }^{13} I d$. $\$ \$ 627,628$, and cases cited.

${ }^{10}$ Id. $\$ 1067$.
} 
the law of alimony was largely shaped and fixed she had no property apart from her husband and had no means of securing help if she left him or called him to a legal accounting of his husbandry, today she has her separate property, and ways and opportunities at least as many, if not more, of earning a livelihood outside the home and independently of her spouse. The natural difference in sex and the abiding fact that it is she who bears and nurtures the offspring is nearly the only stable factor in the marital relationship as we find it today.

It is inevitable that this rise toward parity should alter the old justification for alimony. And by the same reasoning it is logical that the written law should have extended the principle of alimony to conditions of support after the marriage relation has been completely severed. Marriage having changed its complexion from that of a sacrament controlled by the Church to that of social status hedged about more by civic necessities and less by ecclesiastical precepts, it has become the effort of the law to keep the institution of the family vigorous and effective by becoming more lenient with both spouses and less demanding in its admonitions of virtue and obedience. And it is natural under these conditions also that the trend of the written law should be to leave the disposition of property on divorce, together with the terms of the decree for alimony, more and more to the discretion of the court. ${ }^{\mathbf{1 6}}$

It would seem, further, to be a reasonable consequence of the changed social position of woman that attitudes toward divorce would show decreasing disapproval. People generally realize the economic strain that now attends family life. They see the wife forced to carry on a tour of labor or of professional work outside the home. They find the husband harassed by the struggle for means of support of himself and his family. Hence they look with some leniency upon the parties when quarreling and discontent arise in the home. They are less prone to condemn the wife for seeking divorce or the husband for failing to provide adequate support. Divorce is no longer followed by social ostracism. That which formerly was looked upon as fault and sin, tends nowadays to be viewed as misfortune calling for sympathy. As a consequence of this changing attitude there is a growing feeling that the right to alimony should not be used as an instrument with which to punish a guilty husband; but rather should relate itself definitely to the wife's need and should in no case extend beyond the moment of the wife's remarriage. ${ }^{17}$

Viewing the social circumstances attending the family we find the human breeding lair to remain in its essential needs and objectives just what it has been since the beginning of human experience. But the institution of the family in its social setting has greatly changed with economic and political changes. The family is the primal necessity of society.

Further we find the self-sustained family to be a requisite to social order in a free people. Independence of support by others is a prerequisite to continued independence. Wherefore it becomes a basic purpose in the public ordering of family affairs

\footnotetext{
${ }^{10}$ See 2 Vernier, American Family Laws (1932) §105.

${ }^{17}$ See Deitrick v. Deitrick, 99 N. J. Eq. 711, 134 Atl. 338 (1926); Cropsey v. Cropsey, 104 N. J. Eq. 187,144 Atl. 621 (1929); Southard v. Southard, 262 Mass. 278, 559 N. E. 518 (1928).
} 
to encourage self-support and to avoid by all means the dependency of the family or of any of its members upon the public.

And finally in our examination of the changing conditions of family life we discover almost a complete change in the status of the woman under coverture. No longer is she merged with her husband, powerless to do aught but obey, and in the last extremity appeal to the Church for the equitable remedy of separation and continued support from her husband. She stands forth as his equal before the law. She is appraised his equal by public opinion. And as her rights are looked upon as equal, there is a strong tendency to set her duties on a similar plane of equality. The growing feeling of public resentment against suits brought for breach of promise of marriage in all probability has its roots in the same decline of sympathy for the defenseless woman, no longer without defense.

With this social background in mind it is useful to note briefly the apparent trend in the written law of alimony and in the attitude of courts charged with enforcement. We have already noted its origin as an equitable remedy for the position of the wife when conditions grew intolerable and the husband was an offender against moral tenets. It was not available to her unless she were in need. Nor could she claim it except she be without $\sin$ in respect of her marital relations. It required the husband to continue her support pendente lite.

But as the economic changes in living and labor, already noted, came about the wife's changed status was gradually recognized by legal remedies to the degree even of complete severance of the marriage tie. And in spite of the ill logic of demanding that the husband support her after she ceased to be his wife and the marital situation was completely severed, it was an easy step to insist, by provision incorporated in the divorce decree, that the former husband should go on supporting the erstwhile wife: and this even after she should have married again. ${ }^{18}$

The distinct tendency in the law of alimony is to extend it to the conditions of absolute divorce, but to leave in the discretion of the court the amount of the allowance. ${ }^{19}$ And there is apparent a still further aspect of change, namely, in the direction of merging the specific question of alimony in the broader problem of complete disposition of the property of the parties, joint and several, upon divorce. ${ }^{20}$ There is even an increasing trend to allow alimony to the husband in needy circumstances. ${ }^{21}$

In its present stage therefore we find reasoning in the law of alimony divided into two well-defined and conflicting camps, the one adhering to the historical view, the other yielding old theory to the social demand for new practice. These two views, well expressed by Mr. Justice Cullen in the case of Wilson v. Hinman ${ }^{22}$ are in substance

I. That alimony is a right of the same character as the right of support lost by the dissolution of the marriage.

\footnotetext{
${ }^{18}$ For statutes extending the right thus far, see 2 Vernier, AMerican Family Laws $\$ 105$.

${ }^{10}$ Id. \$104.

${ }^{21} I d . \$ \$ 62$, Iog.

${ }^{20} \mathrm{Ibid}$.

22182 N. Y. 408,75 N. E. 236 (1905).
} 
2. That alimony is a settlement of the property rights of the parties and a distribution of the assets of the quasi-partnership hitherto existing. ${ }^{23}$

The courts still struggle to define the nature of alimony. First they declare that it is not property in the sense that a decree therefor creates a debt. ${ }^{24}$ Then they withdraw from this extreme position to the extent of holding that alimony is property, to be sure, but property of a peculiar kind, calling for the special protection of the court. And this finding provides justification for insisting that it may under no circumstances be diverted from its original purpose. Even the deceased wife's estate is permitted to collect alimony due her in her lifetime, though there is no right to it after the husband's death. ${ }^{25}$

Neither can it be reached by the wife's creditors. It is not discharged in the husband's bankruptcy. Nor can the husband set off against it a debt owed him by the wife. ${ }^{28}$

These wavering views look suspiciously like mere groping on the part of the courts. It is likely that the key to a sound philosophy of alimony will be found only in the social analysis of the family as the primary institution in the State.

Obviously the obligation of a husband to support is not merely a duty sounding in dollars. Obviously, too, the wife should not be the sole arbiter of the disposition of her support thus ordered by the court. It must apply to her support, claims of creditors to the contrary not withstanding. So long as the substantive law continues to cling to the idea that the marriage relation shall be assumed to continue on, through the pressure of requirement to support, the innocent spouse holding the right and the guilty spouse receiving the punishment, just so long will there continue to be confusion in the reasoning behind the adjustment of the marital obligation to support.

Out of these considerations arise three suggestions, at least, for improvement in the law of alimony: two in the substantive law itself and one in the method of its administration.

I. Considerations of guilt or innocence should be eliminated from the law of alimony. The difficulty which alimony seeks to solve is an economic question of reallocating the property out of which support should come during the married state to the circumstances of temporary litigation or permanent dissolution of the old relationship. To consider it a reward of merit for the virtuous or as a punishment for the wrong-doer, is to misconstrue the premises.

In this light discretion should rest with the court to make all necessary adjustment of the property of the spouses to see to it that the maximum of support should be provided for, independent of public tax funds. And in so doing it should be a principle of the law that the welfare of the children is to be served before that of the contending spouses. It may do violence to precedent in legal practice to require that

\footnotetext{
${ }^{23}$ For a helpful discussion of the nature of alimony, see Munson, Some Aspects of the Nature of Permanent Alimony (1916) I6 CoL. L. REV. 217, 222.

24 Faversham v. Faversham, I62 App. Div. 521, I46 N. Y. Supp. 569 (1914).

${ }^{26}$ Burns v. Klug, 29 App. Div. 192, 195; I13 N. Y. Supp. 325, 328 (1908).

so Wilson v. Hinman, supra note 22.
} 
support money for the children should be paid into court or to a third party in the event that the court is not satisfied with the efficiency and reliability of the wife, but socially speaking there might be much to be gained by that course.

2. The idea that alimony goes to the wife and is so permanent that she may go on receiving it after a second marriage, comports little with the true purposes of sound procedure. Alimony should be an adjustment of the property of the pair jointly and severally to serve the needs of the State and the children consonant with the least interference with individual freedom in the spouses that may be practicable. To allow alimony permanently, regardless of the need for support or of subsequent marriage, harks back to the idea that only the two spouses are concerned in the issue, of whom one is guilty and must pay a penalty. The power should rest with the court to revise, rescind or otherwise alter any of its decrees touching the wind-up of the affairs of the broken marriage whenever social expediency renders it wise-and this without waiting for the appearance and entreaty of one or both of the spouses.

3. Finally, as to administration of the law, the settlement of marital difficulties by decree based upon legal reasoning alone is crude and outmoded in the light of present-day social needs. The court in the average divorce case is quite unable to fathom the cause of the difficulty sufficiently to set up a plan for the protection of the State and the well-being of the parties. In most cases the issue is not clear-cut. In view of the fact that the State holds a vital stake in every marriage, the trial of all marital troubles, seeking justice for the parties, should be carried on as a scientific specialty, in a special court dealing constantly and exclusively with domestic relations. Such a court should have complete and exclusive jurisdiction over such causes and adequate jurisdiction over the parties involved, with full power to dispose of the entire issue, including alimony. The court should be given discretion to alter or otherwise amend its decrees for alimony in the interest of the State and the parties, especially the children.

Such a court cannot function effectively if limited to the customary adjunctive services of bailiffs, clerks, counsel and jury. It must have technical services of which two branches are now well recognized and fully defined and tested. These are, first, the psychiatric examination of individuals, so necessary in family trouble cases as an aid and a preventative in behalf of the parties and the most intelligent service to the children; and second, skilled social case work to carry out the disposition made by the court.

It is here submitted that complicated modern life calls for marked intervention of the State in marital affairs to protect society against waste, inefficiency and preventable loss in the conduct of its most vital institution. This intervention should take the form of scientific analysis of family problems and their skillful disposition to the advantage of society and, if may be, of the parties. And if it be said that this suggestion is a long hark from the idea of a tribunal of justice among English-speaking men, the answer is that the law exists to protect and further the social well-being, and that those instruments which the State sets up to further these purposes must keep abreast of the need, and change with changes in the problems they encounter. 